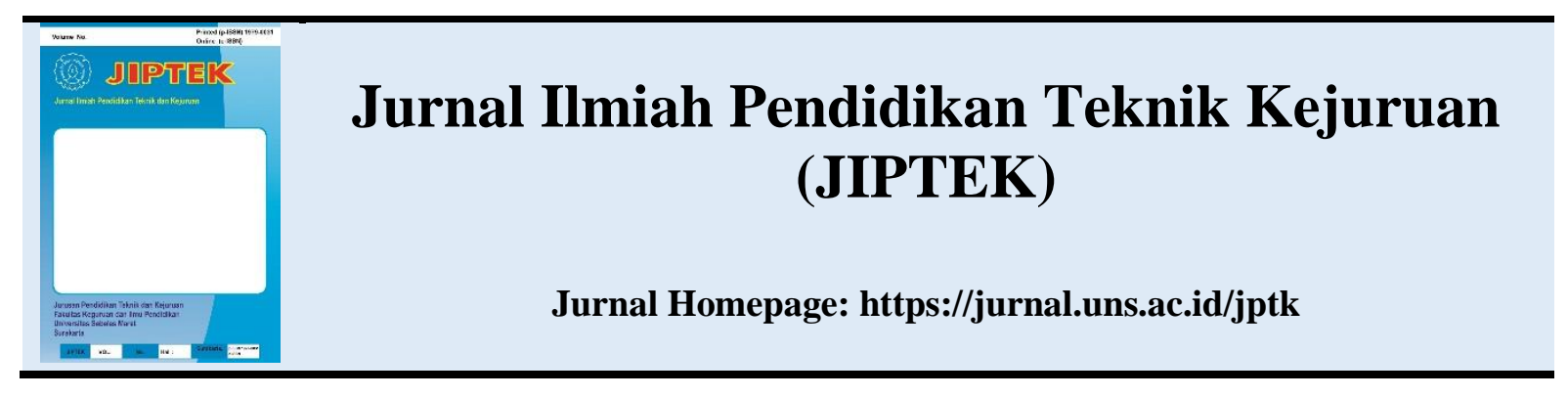

\title{
REKAYASA PENGOLAHAN LIMBAH BATOK KELAPA \\ SEBAGAI AKSESORIS SANGGUL
}

\author{
Erna Setyowati ${ }^{1}$, Atika Puspa $D^{2}$ \\ ${ }^{1,2}$ Pendidikan Tata Kecantikan, Fakultas Teknik, Universitas Negeri Semarang \\ E-mail: nanayw@yahoo.com
}

\begin{abstract}
Abstrak
Limbah batok kelapa banyak dijumpai dibeberapa pasar tradisional, bahkan terjadi penumpukan karena kurang dimanfaatkan secara optimal, sehingga mengakibatkan pencemaran lingkungan, yang selama ini belum mendapat perhatian cara mengatasinya. Tujuan penelitian untuk mengetahui 1).validitas cara pembuatan produk inovatif batok kelapa sebagai aksesoris dan 2). kelayakan rekayasa limbah batok kelapa sebagai aksesoris. Disain eksperimen yang digunakan one shot case study, obyek penelitian/ sampel produk 8 model aksesoris sanggul dan subyek penelitian adalah masyarakat pengguna untuk mengukur kelayakan produk. Uji validitas menggunakan expert judgment dan kelayakan menggunakan uji indrawi dan uji kesukaan. Teknik pengumpulan data menggunakan observasi dan dokumentasi dengan analisis diskriptif persentase. Hasil penelitian validitas produk dari panelis ahli diperoleh $87 \%$, Uji indrawi $84 \%$ dan uji kesukaan $82 \%$ dengan indikator bentuk, ukuran, keserasian dan kekuatan serta ketertarikan. Simpulan adalah aksesoris limbah batok kelapa dinyatakan valid dan rekayasa limbah batok kelapa layak sebagai aksesoris sanggul melalui uji indrawi dan uji kesukaan.
\end{abstract}

Kata Kunci : aksesoris, inovasi batok kelapa, limbah

\begin{abstract}
Coconut shell waste is often found in some traditional markets, there is even accumulation because it is not used optimally, resulting in environmental pollution, which has not received attention to how to deal with it. The aims of this research are to find out 1). the validity of how to craft innovative coconut shell products as a hairbun accessories and 2). the feasibility of crafting coconut shell waste as a hairbun accessories. The experimental design used the one shot case study, the objects of research are samples of 8 models hairbuns accessories and the research subjects were the user community to measure the product feasibility. The validity test is using the expert judgment and the feasibility test is using the sensory tests and the preference tests. The data collection techniques are use the observation and documentation with the percentage descriptive analysis. The results of the product validity test from expert panelists obtained $87 \%$, the result of the sensory test is $84 \%$ and the result of preference test is $82 \%$ with the indicators of shape, size, harmony and strength and interest. The conclusions were that the hairbun accessories from coconut shell waste were declared valid and craft of the coconut shell waste was feasible as a hairbun accessories through the sensory test and the preference test.
\end{abstract}

Key Words : accessories, coconut shell, innovation, waste 


\section{PENDAHULUAN}

Tanaman kelapa (Cocos Nucifera L) merupakan tanaman serbaguna yang mempunyai nilai ekonomi tinggi. Kelapa disebut sebagai "raja serat tropis" dan "pohon kehidupan". Asia Tenggara dianggap sebagai daerah asal kelapa. Batok kelapa adalah bahan alami yang tersedia berlimpah. Batok kelapa banyak digunakan aplikasi dan jumlahnya cukup banyak diekspor (Shruthi, et al. 2018). Seluruh bagian pohon kelapa dapat dimanfaatkan untuk kepentingan manusia, karena hampir seluruh bagian mulai dari 1). akar sebagai obat, 2).batang untuk jembatan maupun mebeler, 3). daun janur untuk selongsong ketupat, 4). lidi untuk sapu, kerajinan anyam, 5). tapas untuk kerajinan tas, 6). mancung digunakan untuk kerajinan lampu dinding, 7). sabut kelapa dapat digunakan untuk kerajiana bunga kering dan 8). buahnya dapat digunakan untuk kehidupan sehari-hari, hingga 9). limbah batoknyapun untuk arang dan masih dapat diolah menjadi kerajinan tas, kancing, pigura, (Ambarawati, dkk. 2007:5). Masalahnya limbah batok ini belum maksimal dimanfaatkan sehingga pembuangannya terjadi penumpukan yang menyebabkan pencemaran lingkungan.

Batok kelapa merupakan limbah dari buah kelapa yang memiliki material paling keras dengan karakteristik warna coklat dengan guratan yang menjadikan daya tarik untuk bahan kerajinan, ketebalan permukaan yang tidak rata, kuat dan tahan air. Berdasarkan Bello et al. (2016), batok kelapa menempati $15 \%$ dari berat total buah kelapa yang berarti sekitar 9 juta ton batok kelapa dibuang secara global setiap tahun. Bahan-bahan ini murah, mudah tersedia dan terbarukan. Secara struktural, batok kelapa mengandung terutama selulosa, hemiselulosa, lignin dan kelembaban. Kerajinan yang dapat diciptakan dari limbah batok kelapa seperti gantungan kunci, jam dinding, lampu hias, gelang, kalung dan lain sebagainya (Taryati, 2010:711), namun belum banyak yang mengolah limbah batok menjadi aksesoris rambut yang memiliki nilai seni dan nilai jual tinggi. Limbah adalah bahan sisa yang dihasilkan dari suatu kegiatan dan proses produksi baik rumah tangga, industri dan sebagainya (Zahra,Lutfia.dkk, 2015:15).

Pada negara berkembang, menurut Anwar et al. (2016), limbah batok kelapa yang melimpah hanya dibuang begitu saja, limbah ini dapat digunakan sebagai bahan potensial atau bahan pengganti dalam industri. Hal ini akan memberi keuntungan ganda dari penambahan nilai moneter batok kelapa dan juga sebagai sarana pembuangan limbah. Pengolahan limbah dapat dilakukan dengan 3 cara yaitu mengurangi (reduce), memakai kembali 
(reuse), dan mendaur ulang (recycle). Recycle merupakan kegiatan mendaur ulang kembali limbah atau benda yang dapat berguna kembali dan memiliki nilai ekonomi (Prihandayani, 2016:52). Limbah batok kelapa dapat direkayasa dengan teknik dibentuk, dihaluskan, diwarnai menjadi produk aksesoris rambut yang layak dipakai.

Aksesoris merupakan hiasan atau pelengkap dari suatu busana yang berfungsi untuk menambah keindahan, mempercantik penampilan seseorang, sehingga memberi percaya diri dan stylis. Jenis aksesori bermacam - macam, seperti perhiasan (anting-anting atau giwang, kalung, gelang, bros), selendang, sabuk, suspender, dasi, syal, sarung tangan, tas, topi, arloji, kacamata, dan pin. Maka banyak wanita yang tertarik dan berminat mengoleksi aksesoris, yang biasanya

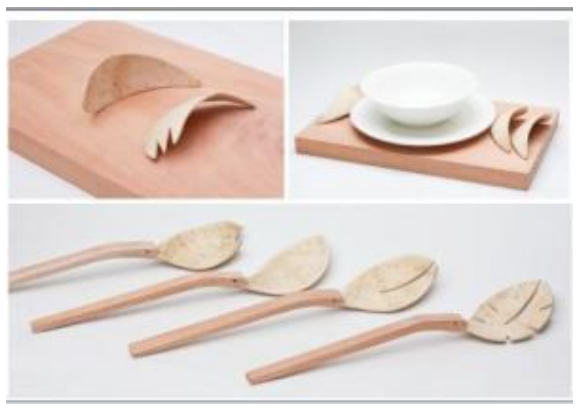

Gambar 1. Produk akhir terbuat dari manik-manik, emas, perak, namun pada penelitian ini akan mengolah limbah batok kelapa menjadi aksesoris untuk sanggul. Tujuan penelitian adalah untuk mengetahui validitas cara pembuatan produk inovatif batok kelapa sebagai aksesoris dan kelayakan rekayasa limbah batok kelapa sebagai aksesoris. Salah satu pengolahan limbah batok kelapa adalah dengan recycle (daur ulang) yaitu melakukan inovasi pembuatan batok kelapa menjadi berbagai macam aksesoris rambut yang digunakan pada sanggul up style dan tradisional.

Limbah batok kelapa yang selama ini telah dimanfaatkan oleh " Surya Tempurung Craft “ dalam bentuk alat musik, cangkir, sendok, mangkuk, asbak, kancing baju, seperti contoh alat makan dibawah ini :

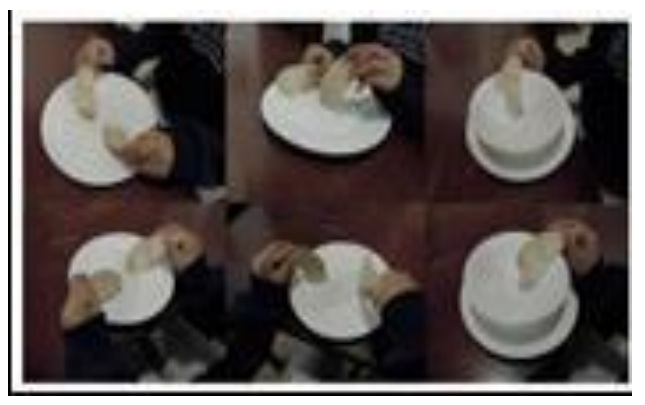

Gambar 2. Uji Pemakaian 
Tabel 1. Rekayasa Pengolahan Limbah Batok Kelapa pada Pola Desain dan Hasil Aksesori

\begin{tabular}{|l|l|}
\hline Limbah batok dengan & Hasil Akhir A 1 \\
pola & \\
\hline dasar aksesoris & Hasil Akhir A2 \\
\hline aksesoris & Hasil Akhir A3 \\
\hline
\end{tabular}

Ciri - ciri Aksesoris dari Limbah Batok

\section{Kelapa Untuk Sanggul}

Dalam pemilihan aksesoris perlu diperhatikan bahan aksesoris, bentuk, ukuran, dan keserasian warna. Jika aksesoris tersebut tidak disesuaikan maka akan mempengaruhi penampilan. Apalagi diaplikasikan untuk penataan sanggul. Sanggul merupakan penataan rambut untuk memperindah bentuk wajah dan 
penampilan seseorang. Penataan rambut up style disebut penataan sanggul modern. Penataan rambut up style adalah suatu tindakan memperindah bentuk rambut pada bagian belakang (back mess), pada bagian atas (top mess), dan bagian depan (front mess) dengan menambah rambut palsu dari hair piece, cemara gepeng atau lungsen sesuai trend dan keinginan, sedangkan penataan rambut tradisional biasanya berbentuk sanggul ukel tekuk ( Yogyakarta ) dan ukel konde ( Solo ). Pengolahan limbah batok kelapa yang direkayasa dibuat aksesoris sanggul nantinya akan dilakukan uji validitas produk oleh expert judgment dan uji kesukaan, selanjutkan diproses hingga aksesoris sanggul dari limbah batok kelapa dapat dikatakan layak dipakai oleh masyarakat.

\section{METODE PENELITIAN}

Metode penelitian ini adalah metode eksperimen. Objek penelitian adalah aksesoris dari limbah batok kelapa dan subjek penelitian adalah 3 panelis ahli yang akan menilai uji indrawi dan 5 responden/model serta 75 masyarakat untuk menilai uji kesukaan produk dan kedua uji tersebut untuk mengukur kelayakan produk.

Sampel produk berjumlah 8 sampel. Desain eksperimen yang digunakan dalam penelitian ini adalah one-shot case study.
Validitas instrument menggunakan expert judgment. Metode pengumpulan data menggunakan observasi dan dokumentasi. Pelaksanaan penelitian dilaboratorium Jurusan Kecantikan FT/Unnes. Teknik analisis data menggunakan deskriptif persentase.

\section{PROSEDUR PENELITIAN}

1. Persiapan Alat dan bahan

2. Tahap pelaksanaan eksperimen

\section{Validitas Pembuatan Produk Inovatif}

Batok Kelapa Sebagai Aksesoris

\section{Persiapan alat dan bahan yang} terdiri :

Tabel 2. Alat dan Bahan

\begin{tabular}{|lr|l|lr|}
\hline 2. & Alat & 6. Gunting & 11. & Lem \\
\hline 3. & Gerinda & 7. Jarun jahit & 12. & Jepit \& \\
\hline 4. & Amplas & 8. Tang & 13. & Cat \\
\hline 5. & Kuas & 9. Limbah batok & 14. Benang \\
\hline 6. & Glue gun & 10. Manik- & 15. Cat kayu \\
\hline
\end{tabular}

\section{Proses Pembuatan Aksesoris Limbah}

\section{Batok Kelapa}

a. Bersihkan batok kelapa dari serabut

b. Potong batok sesuai desain pola aksesoris

c. Menghaluskan

d. Pelapisan cairan pengkilat tahap 1

e. Tahap mewarnai

f. Pelapisan cairan pengkilat tahap 2

g. Merangkai

h. Pemasangan manik-manik 
i. Pewarnaan bagian belakang

j. Pemasangan jepit maupun harnal

k. Finishing

\section{HASIL PENELITIAN DAN}

\section{PEMBAHASAN}

Berdasarkan hasil penelitian yang telah dilaksanakan dan analisis data beserta pembahasannya. Penelitian ini dilakukan terhadap 3 panelis ahli dan 75 responden tidak terlatih yang dilakukan Toko aksesoris Ratu Paksi jalan pemuda no 32
Semarang, dosen ahli dan Christian Richard $\&$ Beauty Salon jalan mayjend Sutoyo 41 Semarang. Uji validitas produk berpedoman pada instrument penilaian dengan kategori yang dinilai bentuk, ukuran, keserasian dan kekuatan pada saat aksesoris dipasangkan pada sanggul.

\section{Penilaian Validator Produk Aksesoris}

Limbah Batok Kelapa oleh Ahli

Akksesoris

Tabel 3. Hasil Validitas Produk

\begin{tabular}{|c|c|c|c|c|c|c|c|c|c|}
\hline \multirow[t]{2}{*}{ No } & \multirow{2}{*}{$\begin{array}{l}\text { Kategori } \\
\text { Pengamatan }\end{array}$} & \multicolumn{8}{|c|}{ Produk Aksesoris } \\
\hline & & A1 & A2 & A3 & A4 & $\mathbf{A 5}$ & A6 & A7 & A8 \\
\hline 1 & Bentuk & 3 & 3 & 4 & 3 & 3 & 4 & 4 & 3 \\
\hline 2 & Ukuran & 3 & 3 & 4 & 3 & 4 & 4 & 4 & 3 \\
\hline 3 & Keserasian & 2 & 2 & 3 & 2 & 3 & 3 & 4 & 3 \\
\hline 4 & Kekuatan & 3 & 3 & 4 & 4 & 3 & 4 & 4 & 3 \\
\hline \multicolumn{2}{|c|}{ Jumlah } & 11 & 11 & 15 & 12 & 13 & 15 & 16 & 12 \\
\hline \multicolumn{2}{|c|}{ Persentasi } & $79 \%$ & $79 \%$ & $94 \%$ & $86 \%$ & $93 \%$ & $94 \%$ & 100 & 75 \\
\hline \multicolumn{2}{|c|}{ Kategori } & $\mathrm{S}$ & $\mathrm{S}$ & SS & SS & SS & SS & SS & SS \\
\hline \multicolumn{2}{|c|}{$\%$ Komulatif } & \multicolumn{8}{|c|}{$87 \%$} \\
\hline \multicolumn{2}{|c|}{ Kategori } & \multicolumn{8}{|c|}{ Sangat Valid } \\
\hline
\end{tabular}

\section{Sumber data : peneliti}

Hasil validitas rekayasa produk aksesoris dari limbah batok kelapa yang memiliki indeks terendah adalah produk A8 ( $75 \%$ ) sedangkan produk aksesoris dengan nilai tertinggi pada A8 ( $100 \%)$, namun secara komulatif dari semua produk aksesoris yaitu $87 \%$ dengan kategori sangat valid. Untuk uji indrawi yang dilakukan oleh 3 panelis ahli menilai 8 produk diperoleh hasil dibawah ini:

Tabel 4. Hasil Uji Indrawi Produk Aksesoris Sanggul

\begin{tabular}{|l|l|l|l|l|l|l|l|l|l|l|l|}
\hline \multirow{2}{*}{ No } & Indikator & \multicolumn{8}{|c|}{ Produk Aksesoris } & Persentase & Kategori \\
& Penilaian & $\mathbf{A 1}$ & $\mathbf{A 2}$ & $\mathbf{A 3}$ & $\mathbf{A 4}$ & $\mathbf{A 5}$ & $\mathbf{A 6}$ & $\mathbf{A 7}$ & $\mathbf{A 8}$ & Rata-Rata & \\
\hline 1 & Bentuk & $83 \%$ & $83 \%$ & $92 \%$ & $75 \%$ & $100 \%$ & $83 \%$ & $92 \%$ & $75 \%$ & $85 \%$ & Sangat Sesuai \\
\hline 2 & Ukuran & $83 \%$ & $83 \%$ & $83 \%$ & $92 \%$ & $100 \%$ & $100 \%$ & $75 \%$ & $58 \%$ & $84 \%$ & Sangat Sesuai \\
\hline 3 & Keserasian & $83 \%$ & $75 \%$ & $92 \%$ & $83 \%$ & $83 \%$ & $83 \%$ & $92 \%$ & $67 \%$ & $82 \%$ & Sangat serasi \\
\hline 4 & Kekuatan & $75 \%$ & $75 \%$ & $92 \%$ & $83 \%$ & $92 \%$ & $92 \%$ & $92 \%$ & $92 \%$ & $86 \%$ & Sangat Kuat \\
\hline$\%$ Komulatif & $81 \%$ & $79 \%$ & $90 \%$ & $83 \%$ & $94 \%$ & $90 \%$ & $88 \%$ & $73 \%$ & $\mathbf{8 4 \%}$ & Sangat layak \\
\hline
\end{tabular}


Sumber data: dokumentasi peneliti

Hasil uji indrawi dari panelis ahli terlihat pada tabel 4.2 menunjukkan bahwa produk aksesoris dengan indeks terendah pada A8 ( $73 \%$ ) dan yang tertinggi A5 (94\%) baik dilihat dari bentuk, kekuatan, ukuran dan keserasian, namun secara rata-rata sebesar $84 \%$ dengan kriteria sangat layak.

\section{Hasil Penilaian Uji Kesukaan}

Uji kesukaan dilakukan 75 responden panelis tidak terlatih. Berikut adalah hasil deskripsi tingkat kesukaan responden pada aksesoris sanggul pada limbah batok kelapa

Tabel 5. Hasil Uji Kesukaan

\begin{tabular}{|l|l|c|c|c|c|c|c|c|c|c|c|}
\hline \multirow{2}{*}{ No } & Indikator & \multicolumn{9}{|c|}{ Produk } \\
\cline { 2 - 11 } & Penilaian & $\mathbf{A 1}$ & $\mathbf{A 2}$ & $\mathbf{A 3}$ & $\mathbf{A 4}$ & $\mathbf{A 5}$ & $\mathbf{A 6}$ & $\mathbf{A 7}$ & $\mathbf{A 8}$ & $\begin{array}{l}\text { Persentase } \\
\text { Rata-Rata }\end{array}$ & \\
\hline 1 & Bentuk & $82 \%$ & $83 \%$ & $88 \%$ & $79 \%$ & $87 \%$ & $84 \%$ & $85 \%$ & $82 \%$ & $83 \%$ & Sangat Suka \\
\hline 2 & Ukuran & $81 \%$ & $83 \%$ & $86 \%$ & $81 \%$ & $85 \%$ & $85 \%$ & $83 \%$ & $78 \%$ & $82 \%$ & Sangat Suka \\
\hline 3 & Keserasian & $79 \%$ & $75 \%$ & $87 \%$ & $80 \%$ & $83 \%$ & $82 \%$ & $81 \%$ & $78 \%$ & $81 \%$ & Sangat Suka \\
\hline 4 & Kekuatan & $72 \%$ & $75 \%$ & $83 \%$ & $76 \%$ & $84 \%$ & $84 \%$ & $85 \%$ & $84 \%$ & $80 \%$ & Suka \\
\hline 5 & Daya Tarik & $83 \%$ & $81 \%$ & $90 \%$ & $82 \%$ & $84 \%$ & $82 \%$ & $85 \%$ & $80 \%$ & $83 \%$ & Sangat Suka \\
\hline \% Komulatif & $79 \%$ & $79 \%$ & $87 \%$ & $80 \%$ & $85 \%$ & $83 \%$ & $84 \%$ & $80 \%$ & $\mathbf{8 2 \%}$ & Sangat Suka \\
\hline
\end{tabular}

Hasil perhitungan uji kesukaan berdasarkan 5 kriteria penilaian yaitu bentuk, ukuran, keserasian, kekuatan dan daya tarik menunjukkan indeks terrendah A1 dan A2 ( 79\% ) dan nilai tertinggi pada A3 ( $87 \%$ ), namun secara rata-rata semua produk aksesoris $82 \%$ dengan kategori sangat suka.

\section{Validitas Cara Pembuatan Produk} Inovatif Batok Kelapa Sebagai Aksesoris

Hasil uji validitas produk dari 8 produk aksesoris yang diteliti menunjukkan valid atau layak untuk dilakukan uji kelayakan produk. Pada uji validitas produk aksesoris yang memiliki nilai paling tinggi yaitu aksesoris A7 dinilai dari bentuk, ukuran, kekuatan, dan keserasian dengan kategori sangat sesuai ,sedangkan aksesoris yang memiliki nilai paling rendah yaitu aksesoris A1 dan aksesoris A2 dinilai dari bentuk, ukuran, kekuatan, dan keserasian dengan kategori sesuai. Sesuai dengan fungsi aksesoris yaitu untuk mempercantik, memperindah dan mempermanis penampilan seseorang. Hal ini sesuai dengan pendapat Zahra, Lutfia,dkk (2015:14) yang menyatakan bahwa aksesoris merupakan pelengkap busana yang berfungsi sebagai penambah keindahan sipemakai.

Hasil Uji Indrawi Aksesoris dari limbah batok kelapa oleh panelis Ahli 
Hasil uji indrawi aksesoris dari limbah batok kelapa sebagai aksesoris sangguul up style dan etnik dari 8 produk aksesoris dinyatakan dengan kategori sangat layak. Produk aksesoris yang mendapatkan persentase tertinggi adalah produk aksesoris A5 dengan kriteria sangat layak karena dinilai dari bentuk dan keserasiannya sangat sesuai dengan sanggul yang dikenakan, ukuran sangat sesuai, mudah dikenakan pada sanggul dan daya kekuatan produknya sangat kuat untuk sanggul up style yang telaknya dibagian belakang dengan model sanggul back style. Pola penataan back style adalah pola penataan yang dilakukan pada bagian belakang atau tengkuk, tepatnya mulai daun telinga atas hingga garis pertumbuhan rambut bagian bawah (Hartini,dkk, 2013:46).

Perolehan hasil uji indrawi paling rendah ada 2 jenis aksesoris yaitu produk aksesoris A2 dan A8 dengan katerori layak. Produk aksesoris A2 memiliki kategori layak karena kekuatan produk aksesoris kurang kuat dan bentuk dari aksesoris kurang menarik untuk sanggul up style yang telaknya dibagian depan dengan model sanggul front style. Pola penataan front Style adalah pola penataan yang difokuskan pada bagian depan. Hasil penataan memiliki ciri utama yakni melebihi garis pertumbuhan rambut bagian depan tepatnya melebihi dahi namun tidak sampai alis mata (Hartini,dkk, 2013:47).

Produk aksesoris A8 dengan kategori layak karena ukuran dari aksesorisnya kurang besar sehingga kurang seimbang dengan ukuran sanggul yang dikenakan. Menurut Rostamailis,dkk (2013:299) dikatakan seimbang jika adanya keseimbangan antara bentuk sanggul dengan besarnya kepala, tinggi tubuh dan kondisi dari rambut itu sendiri, umur dan tujuan pemakaiannya. Teori keserasian ukuran bahwa ukuran merupakan salah satu unsur yang mempengaruhi desain suatu benda. Ukuran yang ideal adalah mempunyai ukuran perbandingan yang tidak jauh dari bentuk tersebut. Produk aksesoris tersebut digunakan untuk sanggul etnik yaitu sanggul ukel tekuk berasal dari daerah yogjakarta.

\section{Hasil Uji Kesukaan Aksesoris dari Limbah Batok Kelapa}

Hasil uji kesukaan aksesoris dari limbah batok kelapa sebagai aksesoris sanggul up style dan etnik dari 8 produk aksesoris dinyatakan dengan kategori sangat layak. Produk aksesoris yang mendapatkan nilai tertinggi adalah produk aksesoris A3 untuk sanggul up style yang telaknya dibagian puncak kepala dengan model sanggul top style dengan kriteria sangat layak karena dinilai dari betuknya sangat menarik dan serasi, sangat sesuai jika dipasangkan pada 
sanggul, mudah digunakan dan daya tahannya sangat kuat perpaduan dari bahan baku aksesoris dan bahan pendukung seperti bulu hias dan manik-manik sangat serasi. Hasil tersebut sesuai dengan pendapat Rostamailis,dkk. tentang salah satu prinsip yang berlaku pada desain sanggul penambahan ornamen/hiasan dari sanggul. Hal ini juga tidak bisa menurut penata kecantikan rambut saja, tapi banyak hal yang harus diperhatikan seperti jumlah ornamen yang akan dipakai, bentuknya, asal bahannya, warnanya, tata letaknya, umur si pemakai, tujuan dan kesempatan.

\section{SIMPULAN}

Berdasarkan hasil penelitian dan pembahasan diperoleh simpulan sebagai berikut :

1. Cara pembuatan produk inovatif batok kelapa sebagai aksesoris sanggul dinyatakan valid oleh panelis sesuai dengan bentuk, ukuran, keserasian dan kekuatan.

2. Kelayakan rekayasa limbah batok kelapa sebagai aksesoris berdasarkan uji inderawi dinyatakan sangat layak, untuk uji kesukaan dinyataan sangat suka. Produk aksesoris yang memiliki perolehan nilai paling tinggi pada uji inderawi adalah produk A5 dan pada uji kesukaan adalah produk A3.

\section{Saran}

1. Produk aksesoris dari limbah batok kelapa lebih di tingkatkan dalam kualitas dan kuantitas sebagai peluang usaha melalui kerjasama dengan pengrajin aksesoris dan pengrajin sanggul

2. Model dapat dikresiakan beraneka ragam mengikuti selera konsumen, sehingga industri kerajinan batok kelapa lebih memperkaya bentuk dan variasi desain aksesoris agar lebih up to date.

\section{DAFTAR PUSTAKA}

Ambarwati, dkk. 2007. Pemanfaatan Kelapa (Batang, Tapas, Lidi, Sabut, dan Tempurung) sebagai Bahan Baku Kerajinan. Jurnal Nasional. Jurnal Nasional

Anwar A, Sabih A, Syed AA. 2016. Performance of Waste Coconut Shell as Partial Replacement of Natural Coarse Aggregate in concrete. International Journal of Scientific \& Engineering Research, Volume 7, Issue 8, ISSN 2229-5518

Bello SA, Agunsoye JO, Adebisi JA, Kolawole FO, Hassan SB. 2016. Physical Properties of Coconut Shell Nanoparticles. Journal of Science, engineering and Technology Vol. 12, No. I, June, 2016, pp 63-79.

Prihandayani, Agustina. 2016. Pelatihan Keterampilan Membuat Aksesoris Rambut (Headpiece) dari Limbah Sisik Ikan bagi PKK Kutisari Indah 
Barat Surabaya. Jurnal Nasional eJournal. Volume 05 Nomer 03 Tahun 2016, Edisi Yudisium Periode Oktober 2016, hal $51-58$

Rostamailis, dkk. 2008. Tata Kecantika Rambut Jilid 3. Jakarta: Direktorat pembinaan Sekolah Kejuruan

Shruthi HG, Harshith MK, Pruthvi M, Sharath KM. 2018. Performance Evaluation of Waste Coconut Shells and Coir Fiber as Substitute for Coarse and Fine Aggregate in Structural Concrete Members. International Research Journal of Engineering and Technology, Volume: 05 Issue: 06 ISSN: 23950056

Taryati. 2010. Industri Kreatif Limbah Tempurung Kelapa. Jurnal Nasional
Jantra Vol. V, No. 9, ISSN 1907 9605

Vony F.S Hartini Hippj, Luthfiyah Nurlaela, Supari Muslim, 2013. Implementasi Perankat Pembelajaran Berbasis Masalah Pada penataan Sanggul up Style Untuk Meningkatkan Hasil Belajar Siswa Di Smk Negeri. Jurnal Pendidikan Vokasi: Teori dan Praktek, ISSN : 2302-285X, Vol.1 No.1

Zahra, Lutfia dkk. 2015. Pemberdayaan Ibu-Ibu PKK Kelurahan Rawa Mangun Dalam Pelatihan Pemanfataan

Limbah Kertas Menjadi Aksesoris Dengan Basis Industri Kreatif. Jurnal Sarwahita Vol.11 No1 